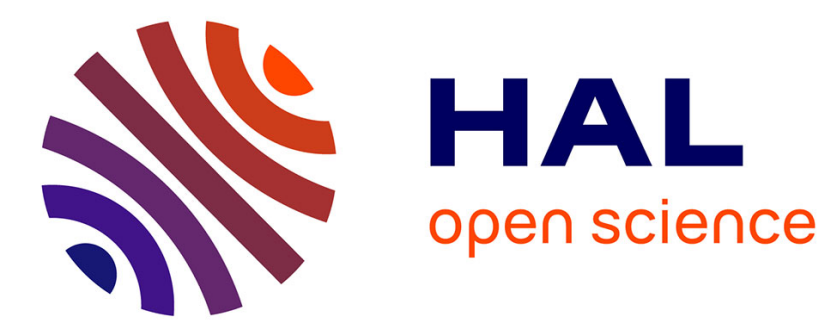

\title{
Facing the risk of upward mobility: \\ Performance-avoidance goals and social class among high-school students
}

\author{
Alisée Bruno, Marie-Christine Toczek, Céline Darnon
}

\section{To cite this version:}

Alisée Bruno, Marie-Christine Toczek, Céline Darnon. Facing the risk of upward mobility: Performance-avoidance goals and social class among high-school students. Journal of Social Psychology, 2020, 160 (4), pp.496-508. 10.1080/00224545.2019.1681353 . hal-02983725

\section{HAL Id: hal-02983725 \\ https://hal.science/hal-02983725}

Submitted on 9 Nov 2020

HAL is a multi-disciplinary open access archive for the deposit and dissemination of scientific research documents, whether they are published or not. The documents may come from teaching and research institutions in France or abroad, or from public or private research centers.
L'archive ouverte pluridisciplinaire HAL, est destinée au dépôt et à la diffusion de documents scientifiques de niveau recherche, publiés ou non, émanant des établissements d'enseignement et de recherche français ou étrangers, des laboratoires publics ou privés. 
Running head: FACING THE RISK OF UPWARD MOBILITY

Facing the Risk of Upward Mobility: Performance-avoidance goals and social class among high-school students

Alisée Bruno $^{1}$, Marie-Christine Toczek-Capelle ${ }^{2}, \&$ Céline Darnon $^{1}$

\section{Affiliations:}

${ }^{1}$ : Laboratoire de Psychologie Sociale et Cognitive (LAPSCO), CNRS UMR 6024, Université Clermont Auvergne, Clermont-Ferrand, France

2: Laboratoire ACTé - Activité, Connaissance, Transmission, éducation - Université Clermont Auvergne, Clermont-Ferrand, France 


\begin{abstract}
Recent research has shown that lower social class students are more likely to endorse performance-avoidance goals (i.e., the fear of performing poorly) than higher-class students, particularly in situations of success (Jury, Smeding, Court \& Darnon, 2015). The purpose of the present research is, first, to test the upward mobility process as a moderator of the link between social class and performance-avoidance goal endorsement. The second aim is to document the further impact of this process on academic performance. Two hundred and fifteen high school students $\left(M_{\text {age }}=17.40, S D=0.69\right)$ participated in the experiment. Half of them were randomly assigned to a "mobility salience" condition where they completed a mobility perception scale; while the other half completed a neutral scale. Then, they answered performance-avoidance goal items and solved mathematics, physics and life and earth sciences exercises. Results indicated that the salience of the mobility process increased the effect of social class on both performance-avoidance goal endorsement and mathematic performance. In addition, performance-avoidance goals appeared to be a mediator of the interaction effect between social class and the salience of the mobility process on mathematics performance. No such findings were obtained for physics and life and earth sciences. Taken together, these results support the idea that the prospect of experiencing mobility may be one of the mechanisms behind the difficulties encountered by lower-class students in an academic context.
\end{abstract}

Keywords: Upward Mobility, Social Class, Performance-avoidance goals, Performance, High School. 
Facing the Risk of Upward Mobility: Performance-avoidance goals and social class among high-school students

While the college degree has become pivotal in helping achieve success in society, access to college is out reach for many. Lower-class students, in particular, are more exposed to a variety of stressors, such as a "steeper learning curve" in the transition from high school to college (Bui, 2002; Ishitani, 2006), increased family demands (London, 1989), lack of peer support (Dennis, Phinney, \& Chuateco, 2005), difficulty establishing connections on campus, (Bean \& Metzner, 1985) and financial burdens (Engle \& Tinto, 2008) than their upper-class counterparts. An additional difficulty encountered by lower-class students when they are on the point of enrolling in higher education is that, by achieving a higher level of education than their parents, they are likely to experience an upward mobility process. The goal of the present paper is to test this mobility process as one of the mechanisms responsible for some of the difficulties encountered by lower-class students in the transition from high school to higher education.

\section{Lower social class students and performance-avoidance goal endorsement.}

In the academic context, students can pursue different types of goals. These are referred to as "achievement goals" (Elliot, 2005; Sommet \& Elliot, 2016) and are highly predictive of various academic outcomes. In particular, according to this field of research, individuals can adopt performance-based goals that are focused either on achieving success (i.e., performance-approach goals, focused on the demonstration of superior competence) or avoiding failure (i.e., performance-avoidance goals, focused on the fear of performing poorly, see Elliot, Murayama, \& Pekrun, 2011; Korn \& Elliot, 2016). These latter goals will be the focus of the present research. Indeed, a central issue in the literature is the extent to which 
different goal orientations facilitate or undermine performance, intrinsic motivation or other learning-related outcomes (e.g., Barron \& Harackiewicz, 2001; Midgley, Kaplan, \&

Middleton, 2001). Research has consistently documented that performance-avoidance goal endorsement is associated with many maladaptive outcomes (for a review, Senko, Hulleman \& Harackiewicz, 2011). For example, the endorsement of performance-avoidance goals is often related to surface learning or disorganization (Coutinho \& Neuman, 2008), selfhandicap (Lovejoy \& Durik, 2010), the avoidance of help-seeking when needed (Roussel, Elliot, \& Feltman, 2011), and a low level of intrinsic motivation (Elliot \& McGregor, 2001). Endorsing performance-avoidance goals also favors negative emotions such as shame or anxiety (Putwain, Sander, \& Larkin, 2013) and a low sense of self-efficacy (Deemer, Carter, \& Lobrano, 2010; Elliot et al., 2011). Furthermore, in this research, performance-avoidance goal endorsement has regularly been shown to be associated with poor academic grades (Hulleman, Schrager, Bodmann, \& Harackiewicz, 2010; Van Yperen, Blaga \& Postmes, 2014).

In recent years, some studies conducted in a higher-education context have shown that lower-class students are more likely to endorse performance-avoidance goals than upper-class students (for example, Jury, Smeding, Court et al., 2015). Indeed, people usually tend to believe that students from a higher social class are better at school than students from a lower social class (Desert, Préaux, \& Jund, 2009; Durante, Tablante, \& Fiske, 2017). Consequently, lower-class students are more likely than higher-class students to perceive their intellectual abilities as weak (Ivcevic \& Kaufman, 2013) and have less confidence in their ability to succeed in college, even when they have the same level of high school preparation and achievement as their peers from a higher social class (Engle, 2007). Furthermore, lower-class individuals are likely to feel negative emotions, such as less personal control over events (Kraus, Piff, \& Keltner, 2009), a fear of not being respected or considered trustworthy (Kraus, 
51 Tan, \& Tannenbaum, 2013) and they are more anxious to be "like everyone else" (Kraus, Piff, \& Keltner, 2011; Kraus, Piff, Mendoza-Denton, Rheinschmidt, \& Keltner, 2012). Other studies have shown that lower-class students experience a cultural mismatch in the university system (Stephens, Townsend, Markus, \& Phillips, 2012) and have to face a negative stereotype associated with their group (Croizet \& Claire, 1998; Steele \& Aronson, 1995) which can, in turn, reduce their performance levels. All these negative experiences may be related to the adoption of performance-avoidance goals. In the present paper, we argue that another mechanism may push lower-class students to endorse more performance-avoidance goals than upper-class students: The social mobility process they are on the point of engaging in.

\section{The social mobility of lower-class students}

Although the perspective of upward mobility should be encouraging for lower-class students, research suggests that higher education is a new and often unfamiliar environment for them. Once at university, lower-class students are often overwhelmed by their environment, which is filled with new expectations, rules and norms (McCarron \& Inkelas, 2006). In addition, the parents of lower-class students are often unfamiliar with the difficulties and disadvantages their children face at university and cannot help them to overcome these challenges (Engle \& Tinto, 2008). Jetten, Iyer, Tsivrikos, and Young (2008) have shown that, in a university context, lower social class students experience a greater sense of incompatibility when they enter university and identify less with university life than higher social class students. Compared to higher social class students, they also report feeling like "outsiders" in the college context and feeling as if they do not "belong" in this environment (Lee \& Kramer, 2013, Ostrove \& Long, 2007, Rubin, 2012). Indeed, people who leave their original social group to access a more privileged social group may be subject to double discrimination (Warner, Hornsey, \& Jetten, 2007): Discrimination from their new group since 
they do not share their rules and / or from their former group for their disloyalty (Travaglino, Abrams, Randsley de Moura, Marques, \& Pinto, 2014). Moreover, many low social class students typically adopt a specific role within the family. Once at university, they want to continue to contribute to their families while still keeping on track with academic tasks and demands (Covarrubias \& Fryberg, 2015; Vasquez-Salgado, Greenfield, \& BurgosCienfuegos, 2015). Thus, the process of upward mobility involves identity change and this change may be particularly difficult for lower-class students (Amiot, Terry, Wirawan, \& Grice, 2010). To cope with this identity change, students may endorse several strategies. The adoption of performance-avoidance goals could be one of them.

Arguing that the upward mobility process is one of the mechanisms underlying the effect of social class on performance-avoidance goal endorsement, Jury, Smeding, Court \& Darnon (2015) have shown that lower-class college students who are high academic achievers more specifically endorse more performance-avoidance goals than higher-class college students. Indeed, the higher the previous academic grade level, the greater the effect of social class on performance-avoidance goal endorsement. Similarly, a lab study conducted by Jury, Smeding and Darnon (2015) showed that the effect of social class on interest in a cue that may indicate poorer performance than others (a behavioral measure of performanceavoidance goal endorsement) increased with participants' initial performance on the task. This moderation of the effect of social class by the initial level of achievement is interpreted in the light of the fact that lower-class high performers are the students who are most exposed to the upward mobility process. Indeed, by succeeding in their academic tasks, lower social class students are likely to obtain a higher education diploma and thus experience upward mobility. Further support for this explanation in terms of the upward mobility process can be found in recent research testing the effect of positive and negative feedback on the evolution of performance-avoidance goal endorsement (Jury et al., 2018). Indeed, this research indicates 
that the level of performance-avoidance goal endorsement increases after positive feedback for lower-class students and after negative feedback for higher-class students, supporting the idea that mobility is a situation that favors performance-avoidance goal endorsement. The study in question also found that the perception of upward mobility mediates the link between social class and performance-avoidance goal endorsement.

All in all, this research suggests that successful lower-class students who are on the point of achieving mobility are particularly likely to endorse performance-avoidance goals. However, these studies present limitations that have to be addressed before we can draw conclusions about the role of upward mobility in explaining the differences in performanceavoidance goals and performance as a function of social class. First, in these studies, mobility was either evoked as a possible mechanism to account for the moderation of the effect of social class by academic level (Jury et al., 2015a, 2015b), or measured as an individual perception (Jury et al., 2018). Manipulating the salience of the upward mobility process would make it possible to draw clearer conclusions about the causal link between social mobility and performance-avoidance goal endorsement. Second, this research was conducted among university psychology students. A replication of the findings among a population that has not yet entered university would involve a sample that is both more gender-balanced and more heterogeneous in terms of social class. Finally, although this previous research has established the associations between social class and performance-avoidance goals, these studies did not measure further academic performances. As indicated above, the endorsement of performance-avoidance goals is usually negatively related to performance (Hulleman et al., 2010; Van Yperen et al., 2014), particularly among low social class students (Bruno, Jury, Toczek-Capelle, \& Darnon, 2019). Consequently, it seems reasonable to assume that a greater endorsement of performance-avoidance goals may mediate the effect of social class and mobility on academic performance. 


\section{Overview and hypotheses}

The present study was conducted among high school students a few months before deciding whether or not to enroll in higher education. The salience of the upward mobility process was manipulated by asking students to answer either a mobility or a neutral scale. We expected the salience of the mobility process to moderate the effect of social class on performance-avoidance goals and on performance on three topics : Mathematics, physics, and life and earth sciences. More precisely, lower-class students should endorse more performance-avoidance goals and perform worse than upper-class students, and this should be particularly true when the upward mobility process is made salient. Furthermore, we hypothesized that performance-avoidance goals would mediate the interaction between social class and upward mobility in terms of performance. Thus, in a mediated moderation model, performance-avoidance goals were tested as a mediator of the moderating effect of the salience of mobility on the relationship between social class and performance.

\section{Method}

\section{Participants}

An a priori power analysis was conducted on $\mathrm{G}^{*}$ Power (Faul, Erdfelder, Lang, \& Buchner, 2007) to determine the sample size. Based on low effect sizes usually observed in research about social class' effects, $\left(\eta p^{2}=.04\right), 191$ participants were required by using an ANCOVA with fixed effects (SES and salience of mobility) and their interactions with an alpha level of .05 and a power level of .80. Gender and initial achievement (mean centered) were entered as covariates in the power compute. To increase safety margins and since we expected to lose some participants because of missing values, we planned to run 230 participants. Two hundred and thirty-three $12^{\text {th }}$ grade students specializing in sciences participated in the study during a classroom lesson. Because data was missing for fifteen 
participants on the subjective SES measure, our final sample included 215 participants: 102 girls and 113 boys, with a mean age of 17.40 years $(S D=0.69)$. The questionnaires were completely anonymously and the study received the approval of the Human Protection Committee (2016/CE 104). The material and the raw data are available on OSF at https://osf.io/enqfk/.

\section{Procedure and Materials}

The experiment was presented as being part of a national survey on success in high school. First, the participants were randomly assigned to a "Mobility Salience" vs. a control condition. To that purpose, they completed either a scale of perception of social mobility (Mobility Salience condition), or a scale measuring the distance between their homes and high school (Control condition). All the participants then completed a measure of performanceavoidance goals as well as multiple-choice tests in mathematics, physics and life and earth sciences and also indicated their subjective SES rank.

Manipulation of the salience of the mobility process. In order to manipulate the salience of the mobility process, participants completed either a 7-points mobility scale (e.g., "You are at high school and, in few months, you are going to take the school-leaving examination. Do you think this level of education is much lower (1)/equivalent (4)/much higher (7) than the one obtained by the most educated of your parents?", "In your opinion, the degree you plan to obtain after the school-leaving examination will be much lower/equivalent/much higher than the one obtained by the most educated of your parents?" $N$ =113); or a distance from high school scale ("In your opinion, the distance from your home to your high school is much shorter (1)/equivalent (4)/much longer (7) than that of other high school students?" (Control Group, $N=120$ ). This procedure was inspired by the procedure used by Kudrna, Furnham, and Swami (2010) for manipulating social class salience. 
Performance-avoidance goals. The three-item performance-avoidance scale was taken from Elliot and Mc Gregor's (2001) Achievement Goal Questionnaire. The questions referred to the participants' studies "in general". The participants indicated their degree of agreement on a 7-point scale, ranging from (1) "totally disagree" to (7) "completely agree" (e.g., "I just want to avoid doing poorly in my studies"). The responses were averaged to form a performance-avoidance score $(\alpha=.56, M=4.64, S D=1.39)$.

Mathematics, Physics, and life and science performance tests. For each topic, we wanted the performance measures to be as close as possible to the exams students regularly take in this course. In accordance with participants' teachers, we have therefore extracted some questions from previous years' baccalaureate exams, i.e., the official exam that students take at this level. All were multiple choices questions. There were four possible answers for each selected question and only one was correct. The participants first answered the mathematics test which contained four questions $(M=1.17, S D=0.94)$. Then, they answered the physics test which contained three questions $(M=2.06, S D=0.77)$. Finally, the life and science test was composed of three questions $(M=1.55, S D=0.98)$.

Subjective SES rank. Social class was measured using the MacArthur Scale of Subjective Socioeconomic Status (Adler, Epel, Castellazzo, \& Ickovics, 2000; Kraus, Piff, \& Keltner, 2009). Indeed, contrary to most research conducted in a higher education context and thus, using parental level of education as a proxy for social class (e.g., Stephens et al., 2012; 2014), the present study was conducted on a population of high school participants. Thus, in conformity with what was done in the past with such a population (see for exemple, Goodman, Adler, Kawachi, Frazier, Huang, \& Colditz, 2001), we choose to measure social class by subjective SES. To indicate where they stood relative to others in their community in France, the participants were asked to place an " $\mathrm{X}$ " on one of 10 rungs of a ladder that represented people with different levels of education, income, and occupational status. Each 
rung of the ladder was represented by a number from 1 to 10 , with higher numbers indicating a higher perceived social $\operatorname{rank}(M=5.78, S D=1.66)$.

Initial academic achievement. Previous research has shown that both social class and performance-avoidance goals are usually related to academic achievement. Thus, in order to control for the variance due to initial academic achievement, the participants were asked to report the mean grade obtained during the second quarter of the year in mathematics $(M=$ $10.42, S D=3.96)$, physics $(M=11.51, S D=2.99)$ and life and earth science $(M=11.88, S D$ $=2.64)$. Each of these grades could range from 0 to 20. Intercorrelations among variables are presented in Table 1.

\section{Results}

Overview of the analyses. Regression analyses were conducted to test whether SES interacted with the mobility manipulation in predicting performance-avoidance goals and each performance score. The regression analyses included three predictors: subjective SES (meancentered), mobility manipulation ( -0.5 for the control condition and +0.5 for the mobility condition), and their interaction. Gender ( -0.5 for boys and +0.5 for girls) and initial achievement (mean centered) were entered as covariates. It is worth noting that the "initial achievement" variable entered as a covariate depended on the model. Indeed, mean initial achievement was entered as a covariate for the analyses conducted on the performanceavoidance score; initial achievement in mathematics was entered as a covariate for the analyses conducted on the mathematic test performance; initial achievement in physics was entered as a covariate for the analyses conducted on the physic test performance and initial achievement in life and earth science was entered as a covariate for the analyses involving the life and earth science test. Since none of the IVs were related to gender nor to initial 
achievement, the interactions between gender, initial achievement and the IVs were not retained in the final model (Muller, Yzerbyt, \& Judd, 2008).

\section{Performance-avoidance goals.}

Neither the main effect of SES, $B=0.03, t(207)<1$, nor the main effect of mobility, $B$ $=0.22, t(207)=1.20, p=.23$, were significant. More importantly, and as expected, SES interacted with mobility, $B=-0.28, t(206)=-2.45, p<.02, \eta p^{2}=.03,95 \%$ CIs $[-0.50,-0.05]$. This interaction is depicted in Figure 1. Simple slope analyses revealed that the lower-SES students who answered the mobility scale endorsed more performance-avoidance goals than the lower-SES students in the control condition, $B=0.69, t(207)=2.61, p=.01, \eta p^{2}=.03$, 95\% CIs $[0.17,1.21]$. No such difference was observed among the higher-SES students, $B=-$ $0.2, t(207)<1$.

\section{Performance in mathematics.}

The main effect of SES was significant, $B=-0.08, t(205)=-2.14, p=.034, \eta p^{2}=.02$, 95\% CIs [-0.16, -0.01]. Surprisingly, the lower-SES students achieved better performances in mathematics than the higher-SES students. The main effect of mobility was marginal, $B=-$ $0.22, t(205)=-1.74, p=.08, \eta p^{2}=.02,95 \%$ CIs $[-0.47,0.03]$ and indicated that making the mobility process salient further reduced performance. Indeed, when the mobility process was made salient $(M=1.10 ; S E=.94)$, the students tended to have worse performance scores than in the control condition $(M=1.25 ; S E=.94)$. As expected, SES interacted with the mobility manipulation, $B=0.325, t(205)=4.14, p<.01, \eta p^{2}=.03,95 \%$ CIs $[0.17,0.47]$. As illustrated in Figure2, simple slope analyses revealed that the lower-SES students for whom the mobility process had been made salient achieved worse performances in mathematics than the lowerSES students in the control condition, $B=-0.74, t(205)=-4.20, p<.01, \eta p^{2}=.05,95 \%$ CIs [$1.09,-0.39]$. No such difference was observed among the higher-SES students, $B=0.31$, $t(205)=1.70, p=.09$. 


\section{Performance in physics.}

Neither the main effect of SES, $B=-0.01, t(206)<1$, nor the main effect of mobility, $B=-0.14, t(206)=-1.23, p=.22$, were significant. Moreover, contrary to our expectations, SES did not interact with the mobility manipulation $B=0.02, t(206)<1$.

\section{Performance in life and earth sciences.}

Neither the main effect of SES, $B=0.01, t(179)<1$, nor the main effect of mobility, $B$ $=-0.02, t(179)<1$, were significant. Moreover, contrary to our expectations, SES did not interact with the mobility manipulation $B=0.11, t(179)=1.19, p=24$.

\section{Mediated Moderation.}

Our final hypothesis was that the effect of the interaction between SES and the mobility manipulation on performance would be mediated by performance-avoidance goal endorsement. In order to test this hypothesis (Figure 3), mediated moderation analyses were run (see Muller, Judd, \& Yzerbyt, 2005). Given that our moderation hypothesis was confirmed only on performance in mathematics, we only tested the mediated moderation model on performance in mathematics. A first model assessed the significance of the SES $\mathrm{x}$ mobility condition effect on performance in mathematics (i.e., c path), while a second model estimated the SES x mobility condition effect on the performance-avoidance goal endorsement (i.e., a path). As these two models had already been estimated (see previous regression analyses), with both interaction effects being significant, we estimated the following final model. As expected, the results showed that the higher the level of performance-avoidance goal endorsement, the lower the performance in mathematics was, $B$ $=-0.09, S E=0.05,95 \%$ CI $[-0.18,0.00], p=.05$ (b path), while the effect of SES on performance in mathematics was non-significant, $B=-0.07, \mathrm{p}=.06$ (c' path). Further analysis indicates that the indirect effect of SES on performances in mathematics through the adoption of performance-avoidance goals was significant only for the lower-SES students for 
whom the mobility process had been made salient, -.21, 95\% CI [-.31; -.11]. This indirect effect was not significant for lower-SES students in the control group, .06, 95\% CI [-.04; .18]. Preacher and Hayes's bootstrap method, using PROCESS SPSS macro, Model 8, confirmed the significance of the indirect effect, via performance-avoidance goal endorsement, of the social class $\mathrm{x}$ upward mobility condition interaction on performance in mathematics, $B=0,01$ $S E=0.01$, with a BC of $95 \%$ and a CI of 0.00 to 0.04 .

\section{Discussion}

The goal of the present research was to test the role of the social mobility process in explaining why low-SES high achievers usually tend to endorse more performance-avoidance goals than high-SES high achievers (Jury et al., 2015, 2018). In addition, our goal was to document further effects of the endorsement of such goals on academic performance. The present results support the idea that when the prospect of social mobility is made salient, lower-class high school students are more likely than higher-class high school students to endorse performance-avoidance goals. As previously mentioned, social mobility involves identity change (Amiot et al., 2010), a change that seems to lead lower-class students to use protective mechanisms because they are afraid of potential failure (e.g., performanceavoidance goals). This result is consistent with previous research showing that lower-class students who endorsed more performance-avoidance goals than higher-class students were those who were the most likely to be engaged in the upward mobility process (e.g., high achievers, Jury et al., 2015; or students who are led to think they are performing better than they usually do, Jury et al., 2018). In addition, the present study provides evidence about the causal link between social mobility and performance-avoidance goal endorsement. Indeed, in the present study, the social mobility process was manipulated, rather than simply being 
evoked as a possible mechanism for explaining the moderation of the effect of social class by academic level.

The results of the present study not only document the existence of a link between social class, mobility, and performance-avoidance goals, they also examine the consequences of this process for academic performance. We hypothesized that when the prospect of social mobility is made salient, lower-class high school students should not only endorse more performance-avoidance goals but should also achieve poorer performances than their higherclass counterparts. Past research has already shown that the adoption of performanceavoidance goals is negatively correlated with academic performance (see meta-analyzes Hulleman et al., 2010; Huang, 2012; Van Yperen et al., 2014). Moreover, researches have shown that lower-class students perform more poorly than higher-class students, particularly in highly evaluative situations (Croizet \& Claire 1998, Berjot \& Drozda-Senkowska, 2007; Smeding, Darnon, Souchal, Toczek-Capelle, \& Butera, 2013). Our results complement these contests by showing that as far as mathematic performances are concerned, such a difference is particularly likely to appear when lower-class participants are reminded of the social mobility process that they are engaged in. Thus, the present results confirm that the prospect of reaching a higher academic level than one's parents might be one of the mechanisms that leads lower-class students to achieve poorer grades in mathematics than higher-class students. In a complementary way, the results obtained on the mathematic performance supported our hypothesis that performance-avoidance goals should mediate the relationship between social class and social mobility in terms of performance.

It is important to note, however, that the above findings are limited to mathematic performance. There might be several reasons why they were obtained on mathematic performance and not other performance scores including the fact that the effect is small, which can cause random variation across different dependent variables. In a future study, a 
more reliable measure of performance should be developed. However, it is also important to note that, mathematic exercises may have been more difficult than other exercises (i.e., the score on the mathematics test was lower than that on the other tests $\left(M_{\text {mathematics }}=1.17, S D=\right.$ $\left.0.94 ; M_{\text {physics }}=2.06, S D=0.77 ; M_{\text {life and earth science }}=1.55, S D=0.98\right)$. Tus, future research should also test the nature of the exercises (mathematics vs. other subjects) or the difficulty of the test as potential moderators of the present findings. In addition, it should be noted that the internal consistency coefficient of the performance-avoidance goal scale was weak. Although this is not unusual in goal-related research using this scale, it would be advisable for future studies to replicate the findings with another, more reliable performance-avoidance goal endorsement scale. Notably, it would be relevant to test whether the revised version of the performance-avoidance goal scale (Elliot \& Murayama, 2008) leads, or not, to the same findings (see Bruno et al., 2019 for a comparison of different performance-avoidance scales). Second, performance-avoidance goals were measured only once. Thus, we cannot exclude the possibility that lower-class high school students and higher-class high school students may have differed on their initial level of goal endorsement, even before we made the process of social mobility salient. In future studies, performance-avoidance goals should be measured twice: before and after the social mobility manipulation is made salient. Finally, it is worth noting that a disadvantage of the mobility manipulation is that it could additionally make salient social class background. In future research, social mobility should be manipulated while maintaining constant the activation of social class. For example, manipulate beliefs about the likelihood to move up and down the socioeconomic ladder (Day \& Fiske, 2016) could be an interesting option.

Despite these limitations, the present findings open up interesting perspectives by showing that the prospect of the social mobility process may be one of the mechanisms behind the difficulties faced by lower-class students in an academic context. In particular, 
they document that the highest level of performance-avoidance goal endorsement on the part of lower-class students confronted with the prospect of mobility may, in turn, negatively affect their performance in a mathematical task. It is worth noting that, so far, research has mainly studied the effect of social class on the adoption of performance-avoidance goals among undergraduate students. The present results nicely complement these findings by showing that a similar process is also observed among a younger, more gender- and SESbalanced sample of high school students.

One might argue that high school students who project themselves into a perspective of upward social mobility (namely, those who plan to enroll in higher education) are not those who most need to be helped, precisely because they are the ones who are succeeding. The present results show that their situation is possibly not as comfortable as it might appear at first sight. Indeed, these students may, on the contrary, be particularly at risk of endorsing performance-avoidance goals and then experience a dramatic fall-off in performance, especially when reminded of the upward mobility situation they are engaged in. Thus, we believe it is important to raise awareness among teachers and educational policy-makers of the fact that lower-class students need to benefit from a high degree of attention in educational interventions, including those students who have the greatest chance of succeeding and achieving a higher educational level than their parents (Stephens, Hamedani \& Destin, 2014; Browman \& Destin, 2016). 


\section{References}

Adler, N. E., Epel, E. S., Castellazzo, G., \& Ickovics, J. R. (2000). Relationship of subjective and objective social status with psychological and physiological functioning: Preliminary data in healthy, White women. Health Psychology, 19(6), 586. doi: $10.1037 / 0278-6133.19 .6 .586$

Amiot, C. E., Terry, D. J., Wirawan, D., \& Grice, T. A. (2010). Changes in social identities over time: The role of coping and adaptation processes. British Journal of Social Psychology, 49(4), 803-826. doi: 10.1348/014466609X480624

Barron, K. E., \& Harackiewicz, J. M. (2001). Achievement goals and optimal motivation: Testing multiple goal models. Journal of Personality and Social Psychology, 80(5), 706. doi: $10.1037 / 0022-3514.80 .5 .706$

Bean, J. P., \& Metzner, B. S. (1985). A conceptual model of nontraditional undergraduate student attrition. Review of Educational Research, 55(4), 485-540. doi: $10.3102 \% 2 \mathrm{~F} 00346543055004485$

Bui, V. T. (2002). First-generation college students at a four-year university: Background characteristics, reasons for pursuing higher education, and first-year experiences. College Student Journal, 36(1). doi: 10.4236/ce.2016.714189

Berjot, S., \& Drozda-Senkowska, E. (2007). Comment les étudiants se perçoivent-ils en fonction de leur origine sociale? Etude de contenu du stereotype [How do students perceive themselves depending on their origin? A study on the content of the stereotype]. Revue Européenne de Psychologie Appliquée/European Review of Applied Psychology, 57(2), 119-132. doi:/10.1016/j.erap.2006.09.002

Browman, A. S., \& Destin, M. (2016). The effects of a warm or chilly climate toward socioeconomic diversity on academic motivation and self-concept. Personality and Social Psychology Bulletin, 42(2), 172-187. doi:10.1177/0146167215619379 
Bruno, A., Jury, M., Toczek-Capelle, M.-C., \& Darnon, C. (in press). Are PerformanceAvoidance Goals Always Deleterious for Academic Achievement in College? The Moderating Role of Social Class. Social Psychology of Education.

Coutinho, S. A., \& Neuman, G. (2008). A model of metacognition, achievement goal orientation, learning style and self-efficacy. Learning Environments Research, 11(2), 131-151. doi: 10.1007/s10984-008-9042-7

Covarrubias, R., \& Fryberg, S. A. (2015). Movin'on up (to college): First-generation college students' experiences with family achievement guilt. Cultural Diversity and Ethnic Minority Psychology, 21(3), 420. doi: 10.1037/a0037844

Croizet, J. C., \& Claire, T. (1998). Extending the concept of stereotype threat to social class: The intellectual underperformance of students from low socioeconomic backgrounds. Personality and Social Psychology Bulletin, 24(6), 588-594. doi:10.1177/0146167298246003

Darnon, B., \& Butera, F. (2005). Buts d'accomplissement, stratégies d'étude, et motivation intrinsèque: présentation d'un domaine de recherche et validation française de l'échelle d'Elliot et McGregor (2001). [Achievement goals, study strategies, and intrinsic motivation: Presentation of a research field and French validation of Elliot \& McGregor's (2001) scale]. L'Année Psychologique, 105(1), 105-131. doi: $10.3406 /$ psy.2005.3821

Day, M. V., \& Fiske, S. T. (2017). Movin'on up? How perceptions of social mobility affect our willingness to defend the system. Social Psychological and Personality Science, 8(3), 267-274. doi: 10.1177/1948550616678454

Deemer, E. D., Carter, A. P., \& Lobrano, M. T. (2010). Extending the $2 \times 2$ achievement goal framework: Development of a measure of scientific achievement goals. Journal of Career Assessment, 18(4), 376-392. doi: 10.1177/1069072710374575 
Dennis, J. M., Phinney, J. S., \& Chuateco, L. I. (2005). The role of motivation, parental support, and peer support in the academic success of ethnic minority first-generation college students. Journal of College Student Development, 46(3), 223-236. doi: $10.1353 /$ csd.2005.0023

Désert, M., Préaux, M., \& Jund, R. (2009). So young and already victims of stereotype threat: Socio-economic status and performance of 6 to 9 years old children on Raven's progressive matrices. European Journal of Psychology of Education, 24(2), 207. doi: 10.1007/BF03173012

Durante, F., Tablante, C. B., \& Fiske, S. T. (2017). Poor but warm, rich but cold (and competent): Social classes in the stereotype content model. Journal of Social Issues, 73(1), 138-157. doi: 10.1111/josi.12208

Elliot, A. J. (2005). A conceptual history of the achievement goal construct. Handbook of competence and motivation, 16(2005), 52-72.

Elliot, A. J., \& McGregor, H. A. (2001). A 2× 2 achievement goal framework. Journal of Personality and Social Psychology, 80(3), 501. doi: 10.1037/0022-3514.80.3.501

Elliot, A. J., \& Murayama, K. (2008). On the measurement of achievement goals: Critique, illustration, and application. Journal of Educational Psychology, 100(3), 613. doi: $10.1037 / 0022-0663.100 .3 .613$

Engle, J. (2007). Postsecondary access and success for first-generation college students. American Academic, 3(1), 25-48.

Engle, J., \& Tinto, V. (2008). Moving beyond access: College success for low-income, firstgeneration students. The Pell Institute for the Study of Opportunity in Higher Education. Washington, DC: Author. doi: 10.12691/aees-2-4-4 
Faul, F., Erdfelder, E., Lang, A.-G., \& Buchner, A. (2007). G*Power 3: A flexible statistical power analysis program for the social, behavioral, and biomedical sciences. Behavior Research Methods, 39(2), 175-191. doi: /10.3758/BF03193146

Goodman, E., Adler, N. E., Kawachi, I., Frazier, A. L., Huang, B., \& Colditz, G. A. (2001). Adolescents' perceptions of social status: development and evaluation of a new indicator. Pediatrics, 108(2), e31-e31. doi: 10.1542/peds.108.2.e31

Hulleman, C. S., Schrager, S. M., Bodmann, S. M., \& Harackiewicz, J. M. (2010). A metaanalytic review of achievement goal measures: Different labels for the same constructs or different constructs with similar labels? Psychological Bulletin, 136(3), 422. doi: $10.1037 / \mathrm{a} 0018947$

Ishitani, T. T. (2006). Studying attrition and degree completion behavior among firstgeneration college students in the United States. The Journal of Higher Education, 77(5), 861-885. doi: 10.1080/00221546.2006.11778947

Ivcevic, Z., \& Kaufman, J. C. (2013). The can and cannot do attitude: How self-estimates of ability vary across ethnic and socioeconomic groups. Learning and Individual Differences, 27, 144-148. doi: 10.1016/j.lindif.2013.07.011

Jetten, J., Iyer, A., Tsivrikos, D., \& Young, B. M. (2008). When is individual mobility costly? The role of economic and social identity factors. European Journal of Social Psychology, 38(5), 866-879. doi: 10.1002/ejsp.471

Jury, M., Bruno, A., \& Darnon, C. (2018). Doing better (or worse) than one's parents: Social status, mobility, and performance-avoidance goals. British Journal of Educational Psychology. doi: 10.1111/bjep.12210

Jury, M., Smeding, A., Court, M., \& Darnon, C. (2015). When first-generation students succeed at university: On the link between social class, academic performance, and 
performance-avoidance goals. Contemporary Educational Psychology, 41, 25-36. doi: 10.1016/j.cedpsych.2014.11.001

Jury, M., Smeding, A., \& Darnon, C. (2015). First-generation students' underperformance at university: the impact of the function of selection. Frontiers in Psychology, 6, 710. doi: 10.3389/fpsyg.2015.00710

Korn, R. M., \& Elliot, A. J. (2016). The $2 \times 2$ standpoints model of achievement goals. Frontiers in Psychology, 7, 742. doi: 10.3389/fpsyg.2016.00742

Kraus, M. W., Piff, P. K., \& Keltner, D. (2009). Social class, sense of control, and social explanation. Journal of Personality and Social Psychology, 97(6), 992. doi: $10.1037 / \mathrm{a} 0016357$

Kraus, M. W., Piff, P. K., Mendoza-Denton, R., Rheinschmidt, M. L., \& Keltner, D. (2012). Social class, solipsism, and contextualism: how the rich are different from the poor. Psychological Review, 119(3), 546. doi: 10.1037/a0028756

Kudrna, L., Furnham, A., \& Swami, V. (2010). The influence of social class salience on selfassessed intelligence. Social Behavior and Personality: an international journal, 38(6), 859-864. doi: $10.2224 /$ sbp.2010.38.6.859

Lee, E. M., \& Kramer, R. (2013). Out with the old, in with the new? Habitus and social mobility at selective colleges. Sociology of Education, 86(1), 18-35. doi: $10.1177 / 0038040712445519$

Lovejoy, C. M., \& Durik, A. M. (2010). Self-handicapping: The interplay between self-set and assigned achievement goals. Motivation and Emotion, 34(3), 242-252. doi: 10.1007/s11031-010-9179-4

McCarron, G. P., \& Inkelas, K. K. (2006). The gap between educational aspirations and attainment for first-generation college students and the role of parental involvement. 
Journal of College Student Development, 47(5), 534-549.

doi:10.1177/0894845314565025

Muller, D., Judd, C. M., \& Yzerbyt, V. Y. (2005). When moderation is mediated and mediation is moderated. Journal of Personality and Social Psychology, 89(6), 852. doi: $10.1037 / 0022-3514.89 .6 .852$

Muller, D., Yzerbyt, V. Y., \& Judd, C. M. (2008). Adjusting for a mediator in models with two crossed treatment variables. Organizational Research Methods, 11(2), 224-240. doi:10.1177/1094428106296636

Ostrove, J. M., \& Long, S. M. (2007). Social class and belonging: Implications for college adjustment. The Review of Higher Education, 30(4), 363-389.

doi: $10.1353 /$ rhe.2007.0028

Putwain, D. W., Sander, P., \& Larkin, D. (2013). Using the $2 \times 2$ framework of achievement goals to predict achievement emotions and academic performance. Learning and Individual Differences, 25, 80-84. doi: 10.1016/j.lindif.2013.01.006

Roussel, P., Elliot, A. J., \& Feltman, R. (2011). The influence of achievement goals and social goals on help-seeking from peers in an academic context. Learning and Instruction, 21(3), 394-402. doi: 10.1016/j.learninstruc.2010.05.003

Rubin, M. (2012). Working-class students need more friends at university: A cautionary note for Australia's higher education equity initiative. Higher Education Research \& Development, 31(3), 431-433. doi: 10.1080/07294360.2012.689246

Senko, C., Hulleman, C. S., \& Harackiewicz, J. M. (2011). Achievement goal theory at the crossroads: Old controversies, current challenges, and new directions. Educational Psychologist, 46(1), 26-47. doi: 10.1080/00461520.2011.538646 
Smeding, A., Darnon, C., Souchal, C., Toczek-Capelle, M. C., \& Butera, F. (2013). Reducing the socio-economic status achievement gap at university by promoting mastery-oriented assessment. PLoS One, 8(8), e71678. doi:10.1371/journal.pone.0071678

Sommet, N., \& Elliot, A. J. (2016). Achievement Goals. Encyclopedia of Personality and Individual Differences, 1-4. doi: 10.1007/978-3-319-28099-8_484-1

Steele, C. M., \& Aronson, J. (1995). Stereotype threat and the intellectual test performance of African Americans. Journal of Personality and Social Psychology, 69(5), 797. doi: 10.1037/0022-3514.69.5.797Stephens, N. M., Hamedani, M. G., \& Destin, M. (2014). Closing the social-class achievement gap: A difference-education intervention improves first-generation students' academic performance and all students' college transition. Psychological Science, 25(4), 943-953. doi: 10.1177/0956797613518349.

Stephens, N. M., Townsend, S. S., Markus, H. R., \& Phillips, L. T. (2012). A cultural mismatch: Independent cultural norms produce greater increases in cortisol and more negative emotions among first-generation college students. Journal of Experimental Social Psychology, 48(6), 1389-1393. doi: 10.1016/j.jesp.2012.07.008

Travaglino, G. A., Abrams, D., de Moura, G. R., Marques, J. M., \& Pinto, I. R. (2014). How groups react to disloyalty in the context of intergroup competition: Evaluations of group deserters and defectors. Journal of Experimental Social Psychology, 54, 178-187. doi: 10.1016/j.jesp.2014.05.006

Van Yperen, N. W., Blaga, M., \& Postmes, T. (2014). A meta-analysis of self-reported achievement goals and nonself-report performance across three achievement domains (work, sports, and education). PloS one, 9(4), e93594. doi: 10.1371/journal.pone.0093594

Vasquez-Salgado, Y., Greenfield, P. M., \& Burgos-Cienfuegos, R. (2015). Exploring homeschool value conflicts: Implications for academic achievement and well-being among 
Latino first-generation college students. Journal of Adolescent Research, 30(3), 271305. doi:10.1177/0743558414561297

388 Warner, R., Hornsey, M. J., \& Jetten, J. (2007). Why minority group members resent impostors. European Journal of Social Psychology, 37(1), 1-17. doi: 10.1002/ejsp.332

390 Yzerbyt, V. Y., Muller, D., \& Judd, C. M. (2004). Adjusting researchers' approach to adjustment: On the use of covariates when testing interactions. Journal of Experimental Social Psychology, 40(3), 424-431. doi: 10.1016/j.jesp.2003.10.001

393

394

395

396 
Table 1.

Zero-order correlations among variables

\begin{tabular}{|c|c|c|c|c|c|c|c|c|c|}
\hline Variables & 1 & 2 & 3 & 4 & 5 & 6 & 7 & 8 & 9 \\
\hline 1. Subjective SES & - & & & & & & & & \\
\hline $\begin{array}{l}\text { 2. Manipulation of } \\
\text { the salience of the } \\
\text { mobility process }\end{array}$ & -.13 & - & & & & & & & \\
\hline $\begin{array}{l}\text { 3. Performance- } \\
\text { avoidance goals }\end{array}$ & .03 & .08 & - & & & & & & \\
\hline $\begin{array}{l}\text { 4. Performance in } \\
\text { Mathematics }\end{array}$ & $-.14 *$ & -.08 & $-.18^{* *}$ & - & & & & & \\
\hline $\begin{array}{c}\text { 5. Performance in } \\
\text { Physics }\end{array}$ & -.01 & -.11 & .03 & .12 & - & & & & \\
\hline $\begin{array}{l}\text { 6. Performance in Life } \\
\text { and Earth Science }\end{array}$ & -.01 & .02 & .02 & $.14^{*}$ & .08 & - & & & \\
\hline $\begin{array}{l}\text { 7. Initial achievement } \\
\text { in mathematics }\end{array}$ & -.06 & .10 & -.03 & .04 & -.02 & .07 & $\ldots$ & & \\
\hline $\begin{array}{l}\text { 8. Initial achievement } \\
\text { in physics }\end{array}$ & -.03 & $.18 * *$ & .01 & -.07 & -.02 & .09 & $.65 * *$ & $\ldots$ & \\
\hline $\begin{array}{l}\text { 9. Initial achievement } \\
\text { in earth and life } \\
\text { science }\end{array}$ & -.01 & .04 & .00 & .04 & .01 & .08 & $.46^{* *}$ & $.60 * *$ & 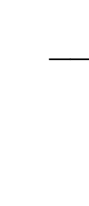 \\
\hline
\end{tabular}




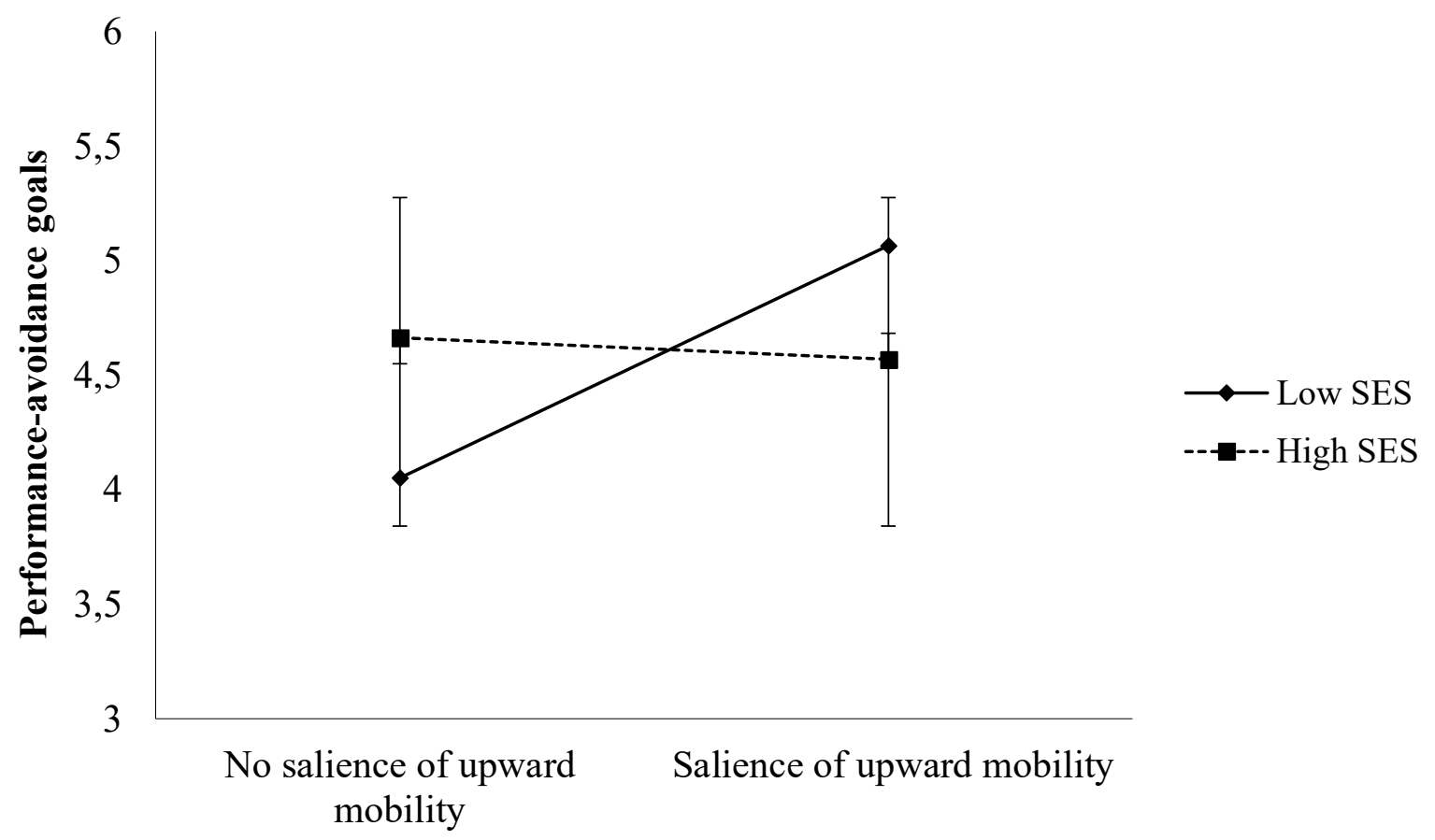

404 Figure 1. Performance-avoidance goals as a function of SES and salience of the Upward 405 Mobility Process. Errors bars represent standard deviation. 


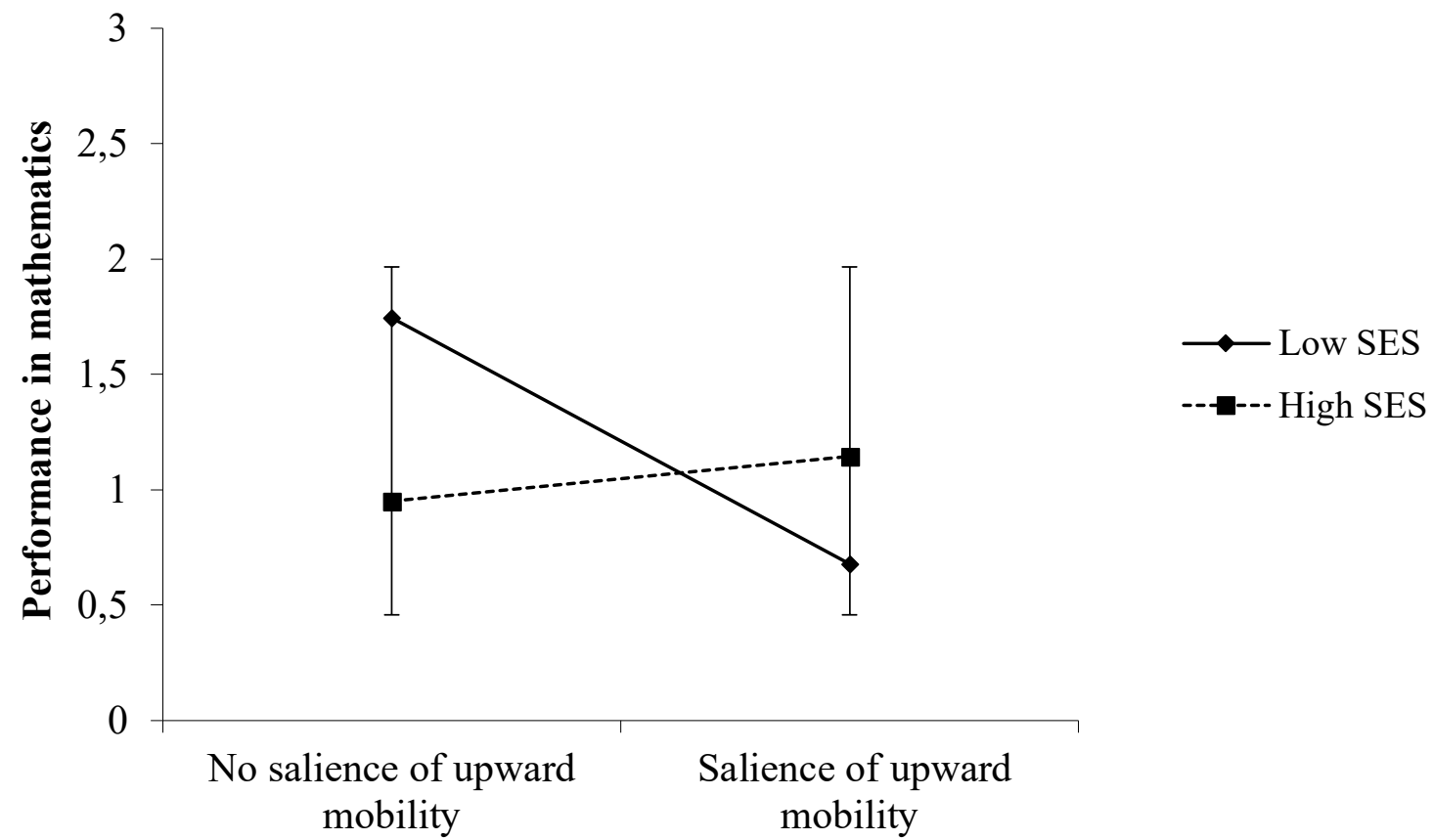

407 Figure 2. Performance in mathematics as a function of SES and salience of the Upward 408 Mobility Process. Errors bars represent standard deviation. 
410

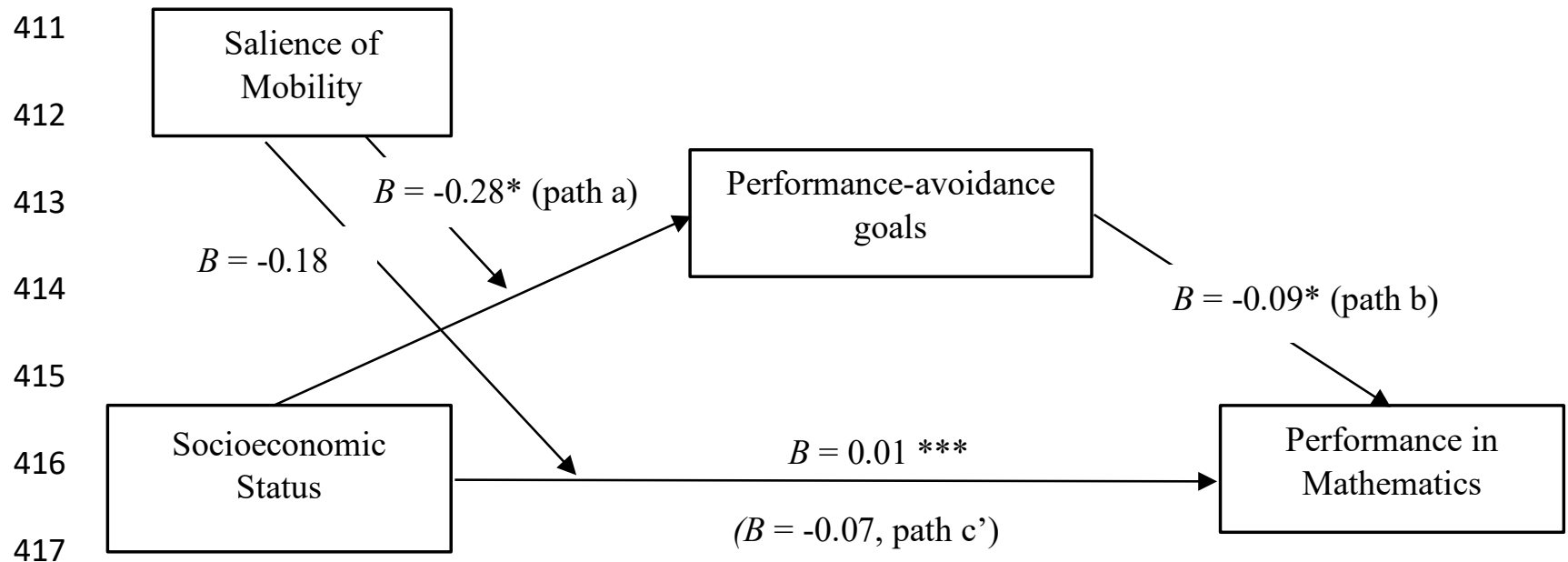

418 Indirect effect: $.01,95 \% \mathrm{CI}=0.00$ to 0.04 , boots $=5000$

419 Figure 3. Indirect effects of the SES (Socioeconomic Status) by Mobility interaction on 420 performance in Mathematics through performance-avoidance goals.

421 Note: Values indicate non-standardized regression coefficients (B) with and without (in

422 brackets) the control of performance-avoidance goals. ${ }^{*} \mathrm{p}<.05 ; * * \mathrm{p}<.01 ; * * * \mathrm{p}<.001$ 